Article received on 3rd August 2012 Article accepted on 24th October 2012

UDC: $785.4 ; 78.071 .1$ Ружичка П.

\author{
Gregor Pompe* \\ University of Ljubljana \\ Faculty of Arts \\ Department of Musicology
}

\title{
PALIMPSEST AND/OR PARODY TECHNIQUE: THE RELATION BETWEEN MODERNISM AND POSTMODERNISM IN PETER RUZICKA'S COMPOSITION TALLIS
}

\section{Postmodernism as a relational term}

One of the main problems of defining postmodernism as a stylistic designation lies in its relation towards modernism. Such dilemmas arise from the linguistic construction of the term: the prefix "post" determines the nature of the relation towards modernism. This relation can be observed on different levels: on the level of time, quality or content. Regarding the historical, time relation, there seems no doubt that postmodernism comes after modernism; however, it is the examination of substantive differences that offers us more possibilities. Many scholars who try to define postmodernism emphasise precisely this somehow obscure relation. Therefore, Helga de la Motte-Haber shifts the problem of the definition from the nature of the prefix to the core of the term itself, ${ }^{1}$ as does Ross Feller, who is convinced that "there exist as many different types

\footnotetext{
* Author contact information: gregor.pompe@ff.uni-lj.si

1 Helga de la Motte-Haber, "Postmodernism in Music: Retrospection as Reassessment", Contemporary Music Review 12 (1995), No. 1, p. 78.
} 
of postmodernisms as modernisms". ${ }^{2}$ The prefix "post" depends on its referent - without it, claims Nikolas Kompridis, it tells us almost nothing. ${ }^{3}$ Such consequent linkage of postmodernism and modernism has even led Hermann Danuser to different definitions of postmodernism (avant-garde and modernist types). ${ }^{4}$

Different possibilities of the relation between modernism and postmodernism on the level of their content can be reduced to three basic models. Postmodernism can be understood as:

a) a completely new style,

b) a reaction against modernism and its abrupt closure, or

c) the continuation and radicalisation of modernism.

The first possibility was convincingly rejected by Italian philosopher Gianni Vattimo, who exposed the paradoxical nature of defining postmodernism as completely new style. ${ }^{5}$ The idea of a completely new beginning incorporates the possibility of surpassing and the notion of progression; however, leading theorists of postmodernism agree that one of its main characteristics lies in the rejection of the comprehension of history as a chain of progressive changes. If postmodernism in its roots rejects the idea of constant innovation and progress, then it cannot be completely new style.

The second possibility is often labelled as "journalistic postmodernism". Such a notion of the relation between modernism and postmodernism was typical of journalism in late seventies and early eighties, when a lot of journalists and publishers warmly welcomed the new style that seemed to replace modernist hermeticism and elitism with open communicativeness and a transgression of the border between high and low culture. The rationality and constructivism of modernism are replaced by the artist's subjective decisions arising from his or her "heart". Typical of such a notion of the new, postmodern style was Leslie Fiedler's influential article "Cross the Border - Close the Gap", which was symptomatically published in Playboy, a magazine "for men". The term "journalistic postmodernism" was coined by a leading German theoretician of postmodernism, Wolfgang Welsch, who warned against definitions of postmod-

\footnotetext{
2 Ross Feller, "Resistant Strains of Postmodernism: The Music of Helmut Lachenmann and Brian Ferneyhough", in: Postmodern Music / Postmodern Thought, ed. by Judy Lochhead and Joseph Auner, New York and London, Routledge 2002, p. 250.

3 Nikolas Kompridis, "Learning from Architecture: Music in the Aftermath to Postmodernism”, Perspectives of New Music 31 (1993), No. 2, p. 7.

${ }^{4}$ Hermann Danuser, "Zur Kritik der musikalischen Postmoderne", in: Quo vadis musica? ed. by Detlef Gojowy, Kassel, Bärenreiter 1990, p. 82.
}

5 Gianni Vattimo, Konec moderne, translated by S. Kutoš, Ljubljana, Literatura 1997, p. 10. 
Pompe, G.: Palimpsest and/or Parody Technique ... (91-107)

ernism derived primarily from a negative attitude towards modernism. ${ }^{6}$ Postmodernism should not be understood simply as anti-modernism, and Thomas Schäfer is convinced that "postmodernism does not have a lot in common with merely irrational-eclectic aesthetics and with new historical realism, traditionalism or subjectivism." 7

Thus the majority of scholars decide in favour of the third possibility, namely that postmodernism continues and radicalises the main characteristics of modernism. According to Charles Jencks, postmodern architecture grows out of modernist architecture, and therefore does not assert "revolutionary" praxis. ${ }^{8}$ Postmodernism continues the modernist tradition, but at the same also surpasses it, mainly in the form of radicalised metaphysical nihilism. ${ }^{9}$ The relation between modernism and postmodernism is therefore not oppositional but dialectical, ${ }^{10}$ or perhaps even dialogical. For Björn Heile, postmodernism "incorporates everything that modernism has excluded". ${ }^{11}$ However, the relation between both styles is even more precisely defined by Welsch. He is convinced that in postmodernism modernist innovations are carried out and realised to their full potential for the first time, and to denote the difference he uses the terms "esoteric" and "exoteric" - that which modernism has tried out in a specialised fashion postmodernism now realises in its full scope. ${ }^{12}$

\section{"Parallel constructing" in the biography and aesthetics of Peter Ruzicka}

I would like to further develop this tense relation between modernism and postmodernism by taking the example of the opus of German contemporary composer Peter Ruzicka. Ruzicka, born in 1948, belongs to the post-war generation that did not have direct contact with the groundbreaking, revolutionary changes of post-war "Darmstadt" modernism. Another date is very telling:

${ }^{6}$ Wolfgang Welsch, Unserepostmoderne Moderne, Weinheim, VCH ${ }^{3} 1991$.

7 Thomas Schäfer, "Anti-Moderneoder Avantgarde-Konzept? Überlegungen zur musikalischen Postmoderne", International Review of the Aesthetics and Sociology of Music 26 (1995), No. 2, p. 221.

${ }^{8}$ Charles Jencks, Jezik postmoderne arhitketure, translated by O. Popović, Belgrade, Vuk Karadžić 1985.

9 Tomo Virk, Strah pred naivnostjo. Poetika postmodernistične proze, Ljubljana, Literatura 2000 , p. 38.

10 T. Schäfer, op. cit., p. 221.

11 BjörnHeile, "Collage vs. Compositional Control: The Interdependency of Modernist and Postmodernist Approaches in the Work of Mauricio Kagel”, in: Postmodern Music / Postmodern Thought, ed. by Judy Lochhead and Joseph Auner, New York and London, Routledge 2002, p. 288.

12 W. Welsch, op. cit., p. 83. 
1968, when Ruzicka began his private compositional studies, was the year that the first postmodern pieces were written (most notably Berio'sSinfonia and Zimmermann's opera Die Soldaten). But Ruzicka's aesthetic ripening followed different paths, independent of the aforementioned contexts of post-war modernism and the first strands of postmodernism.

This curious fact can be explained by two of the composer's central biographical characteristics. Regarding composition, Ruzicka remained an autodidact, and his interests were never limited only to music and composition. Instead of concentrating on one subject, Ruzicka studied diverse disciplines: besides organisational sciences, musicology and theatre studies he also studied law, later even attaining a doctorate as a jurist, but he never studied composition institutionally. Just as varied as his studies were Ruzicka's areas of employment: he was the manager of the Deutsches Symphonie Orchester Berlin, the manager of the Hamburg State Opera, the artistic advisor of the Royal Concertgebouw Orchestra, the director of the Munich Biennial and the Salzburg Festival, professor of cultural management at the Hamburg Musikhochschule, he was engaged with the problems of copyright, and he also worked as an editor and conductor. ${ }^{13}$ As his only composition teacher, it is worth mentioning Hans Werner Henze - a typical "outsider" in the prevailing context of post-war modernism - although later Ruzicka was able to transcend the influence of his teacher.

Considering such biographical facts, which could be interpreted in terms of Brian McHale's designation "parallel constructing", ${ }^{14}$ it comes as no surprise that Ruzicka's composition and aesthetics are highly charged with reflection about music itself. In the seventies, he followed the idea of "critical composing" (kritisches Komponieren). The aim of the latter was to reveal through music the conditions of the production and reception of music and of concert life. Thus his piece Emanazione(1975) for flute and orchestra can be understood as a kind of discussion about virtuosity as an extreme embodiment of emotional expression, and at the same time also as mere fictive and surface pose - reflection that can be linked with Ruzicka's experiences as music manager. Although Ruzicka was trying to find his own distinctive compositional voice, with the idea of "critical composing" he was generally still tied to the main modernist ideas. However, he eventually recognised that the constant demand for new material and procedures was pushing him towards the state in which composition was becoming predominantly decomposition. Ruzicka called this situation the final realisation

13 Uwe Sommer, "Peter Ruzicka", in: Komponisten der Gegenwart, ed. by Hanns-Werner Heister and Wolfgang Sparrer, Munich, edition text + kritik 1992.

14 See Brian McHale, Constructing Postmodernism, London and New York, Routledge 1992. 
Pompe, G.: Palimpsest and/or Parody Technique ... (91-107)

of T. W. Adorno's term musica negativa. At that point, Ruzicka's compositions changed and became more and more inclined towards silence, fragmentation and the breaking up of form and texture, which can be associated with another of Adorno's concepts: the formal category Abbruch, which Adorno attributed to Mahler's symphonies. The predominance of such "fragmentarism" and formal discontinuity is also betrayed by the titles of Ruzicka's compositions from this period: Torso, Abbrüche, ...über ein Verschwinden, Gestalt und Abbruch. The pressure of musica negativa finally led Ruzicka to a short compositional crisis in the years 1979-1981.

Ruzicka found the way out of his compositional silence with the concept of "music about music". He was convinced that it is impossible to find new musical material: "For some time, such an unexploited sound stock has no longer existed. Instead, what one has at one's disposal is a wide spectrum of already tested musical signs, gestures, ciphers and other material 'repertoire' in the broad sense of the word. Nothing is fundamentally new." ${ }^{15}$ Ruzicka no longer believes in the idea of constant progress; his belief in the power of innovation is shattered. This state opens a new relation towards the history of music. Ruzicka observes that radical modernism, as realised in the form of total serialism, led to the loss of the language character of music. He is convinced that the typical modernist quest for "invented" (erfunden) music more and more withdraws in favour of "found" (gefunden) music. In the context of new music, the fragments of "found" music gain special importance, behaving like explicit topics or "semantic enclaves" 16 loaded with "markedness" 17 - although they sound familiar they can also be regarded as foreign elements in the predominant modernist milieu. In this manner, they release musical reflection and huge semantic potential - "music about music", composed on the basis of already existing composition, once more opens the possibility of the restoration of the lost language character of music.

Thus the increased number of quotations, allusions or simulations in Ruzicka's music from the eighties onwards should not be observed as a simple loss of compositional invention or a concession to unreflective traditionalism. The historical material referred to acquires a corresponding sign character - "music

\footnotetext{
15 Peter Ruzicka, “'Den Impulszum Weitersprechen...' Versuch eine smusikalischen Selbstportraits, in: Peter Ruzicka, Erfundene und gefundene Musik, ed. by Thomas Schäfer, Hofheim, Wolke 1998, p. 18.

16 Tibor Kneif, "Anleitungzum Nichtversteheneines Klangobjekts", in: Musik und Verstehen. Aufsätze zur semiotischen Theorie, Ästhetik und Soziologie der musikalischen Rezeption, ed. by Tibor Kneif and Hans-Peter Reinecke, Köln, Arno Volk Verlag and Hans Gerig 1973, p. 167.

17 See Robert S. Hatten, Musical Meaning in Beethoven. Markedness, Correlation, and Interpretation, Bloomington, Indiana University Press 1994.
} 
about music" unleashes "associative counterpoint", ${ }^{18}$ which stems from clashes between different contexts. Ruzicka even asks himself in a radical manner: "In the end, does not the composer's activity today involve only the sorting, choosing and arranging of the given musical material? Should we not search for the composer's invention in the layering of the material and in the combining of found music? Are we not perhaps coming close to the abolishment of the dichotomy, the fundamental discerning between the invented and the found?" 19

\section{Ruzicka's composition Tallis, analysed as palimpsest and/or parody}

Ruzicka's composition Tallis. Einstrahlungen für großes Orchester(1993) can be regarded as typical "music about music". The title itself is revealing: Ruzicka reflects on the forty-part motet Spem in alium by the English Renaissance composer Thomas Tallis (1505-1585). The subtitle of the work - Reflections (Einstrahlungen) - refers to the central compositional idea connected with the "beams" of Tallis'smotet that here and there break through the typical modernist texture. This procedure comes close to the conception of palimpsest but, on the other hand, it could be also compared to the Renaissance parody technique. If we consider the splinters of Tallis's polyphony as an "older" and somehow blurred layer that functions as an intrusion into the "newer" layer, built of typical modernist sound masses, then we are dealing with typical musical palimpsest. However, closer observation of the composition also reveals the possibility of interpretation in terms of the parody technique - Ruzicka develops the whole composition out of a small portion of Tallis's motet. Nonetheless, in both ways we are dealing with the "parallel constructing" of two "worlds" or layers: the modernist layer and non-modernist layer. But such parallelism does not unwind on the level of simple confrontation. Tallis's motet does not function merely as stock for quotation and allusions; it is anchored deeply in the structure of Ruzicka's composition.

Although the whole composition seems as if it had been poured out of one single breath, one can discern two main parts with subsequent transitional passages and a final coda. These parts constitute a typical arch structure stretched from initial calmness to a climactic centre and back to final stillness:

\footnotetext{
18 Thomas Schäfer, “'Verschwiegene Lieder' - ein instrumentales 'Requiem' für Paul Celan”, Die Musikforschung 50 (1997), No. 3, p. 295.

19 Peter Ruzicka, "Erfundene und gefundene Musik. Bemerkungen zu einem bedeutsamen Dualismus der NeuenMusik", in: Erfundene und gefundeneMusik, p. 54.
} 
Pompe, G.: Palimpsest and/or Parody Technique ... (91-107)

Table 1: Formal scheme of Ruzicka's composition Tallis.

\begin{tabular}{|l|l|l|l|l|}
\hline \multicolumn{1}{|c|}{$11^{\text {st }}$ part } & \multicolumn{1}{|c|}{ transition } & \multicolumn{1}{c|}{$2^{\text {nd }}$ part } & \multicolumn{1}{c|}{ transition } & \multicolumn{1}{c|}{ coda } \\
\hline \multicolumn{1}{|c|}{ bars 1-106 } & bars 107-132 & bars 133-169 & bars 170-189 & bars 190-238 \\
\hline I, ${ }^{20}$ II, III, IV, V, & XII, XIII, & XIX, XX, & XXI + XIX, & XXIII, inter- \\
XXIII, Tallis para- & XIV, XV, & three inver- & XX & val e- $a$, cen- \\
phrase (a), VII, VI, & XVI, XVII, & sions of Tallis & & tring around \\
Tallis paraphrase & XVIII + VI, & paraphrase & & \\
(b), VIII, X, IX, & X, XI & $(h-j)+$ V & & \\
$\begin{array}{l}\text { Tallis paraphrase } \\
\text { (c),Tallis quotation } \\
\text { (d), XI, Tallis para- } \\
\text { phrase (e), two for- } \\
\text { ty-part Tallis }\end{array}$ & & & & \\
intrusions (f, g) & & & & \\
\hline
\end{tabular}

Whereas the formal uniformity of the piece is ensured by the arch organisation, the structural unity results from the characteristic treatment of music material. The whole piece is built out of small material splinters:

Example 1: Principal material splinters (I-XIII) for Ruzicka's composition Tallis arranged according to the order of their appearance.

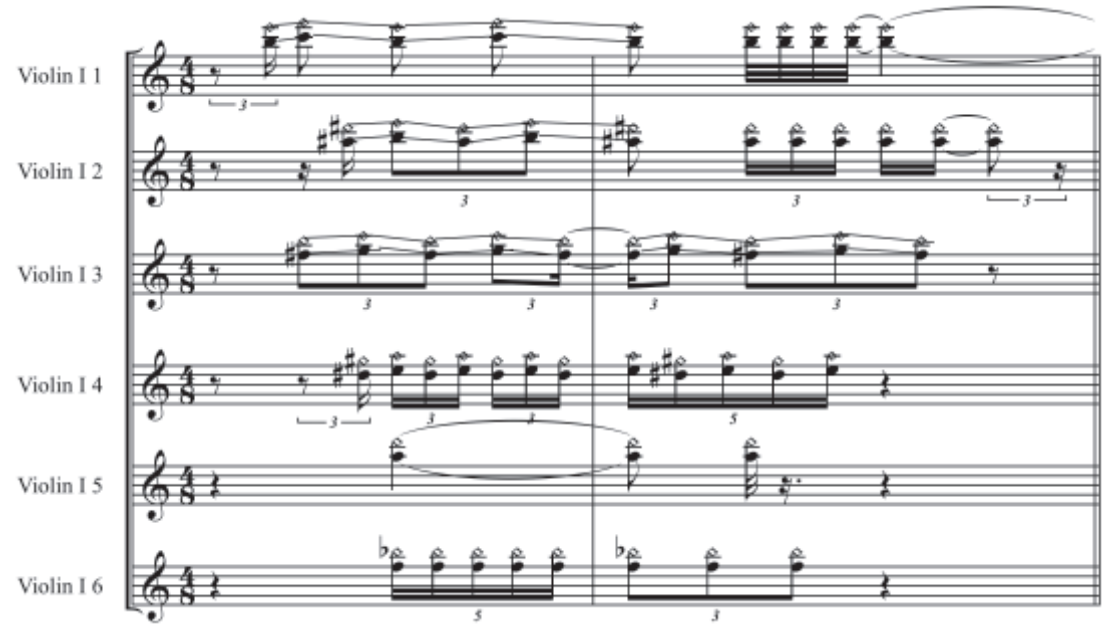

${ }^{20}$ The last row shows the distribution of the material. The Roman numerals mark the material splinters (see example 1) and the letters indicate allusions to Tallis's motet (see example 2). 
New Sound 39, I/2012
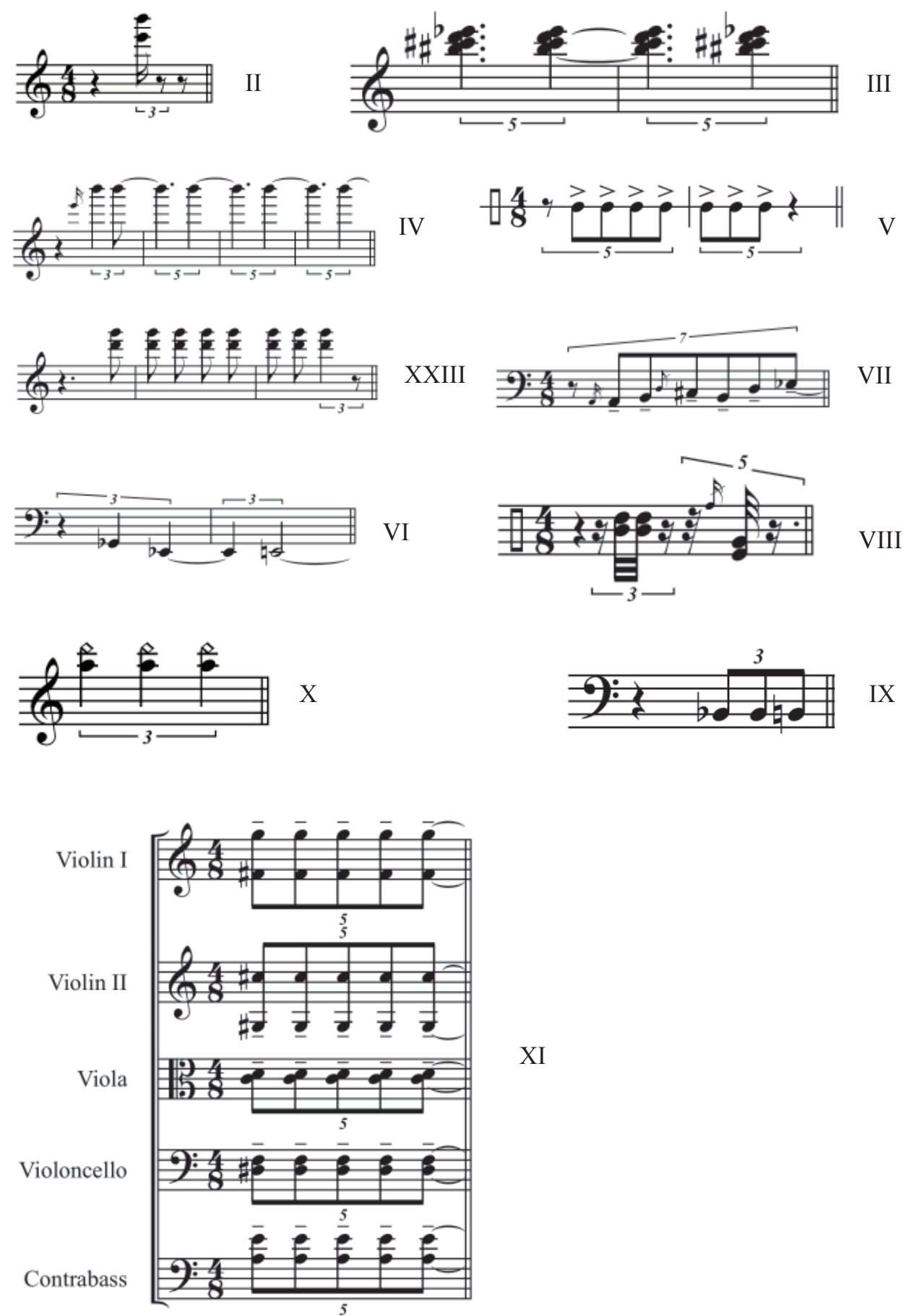

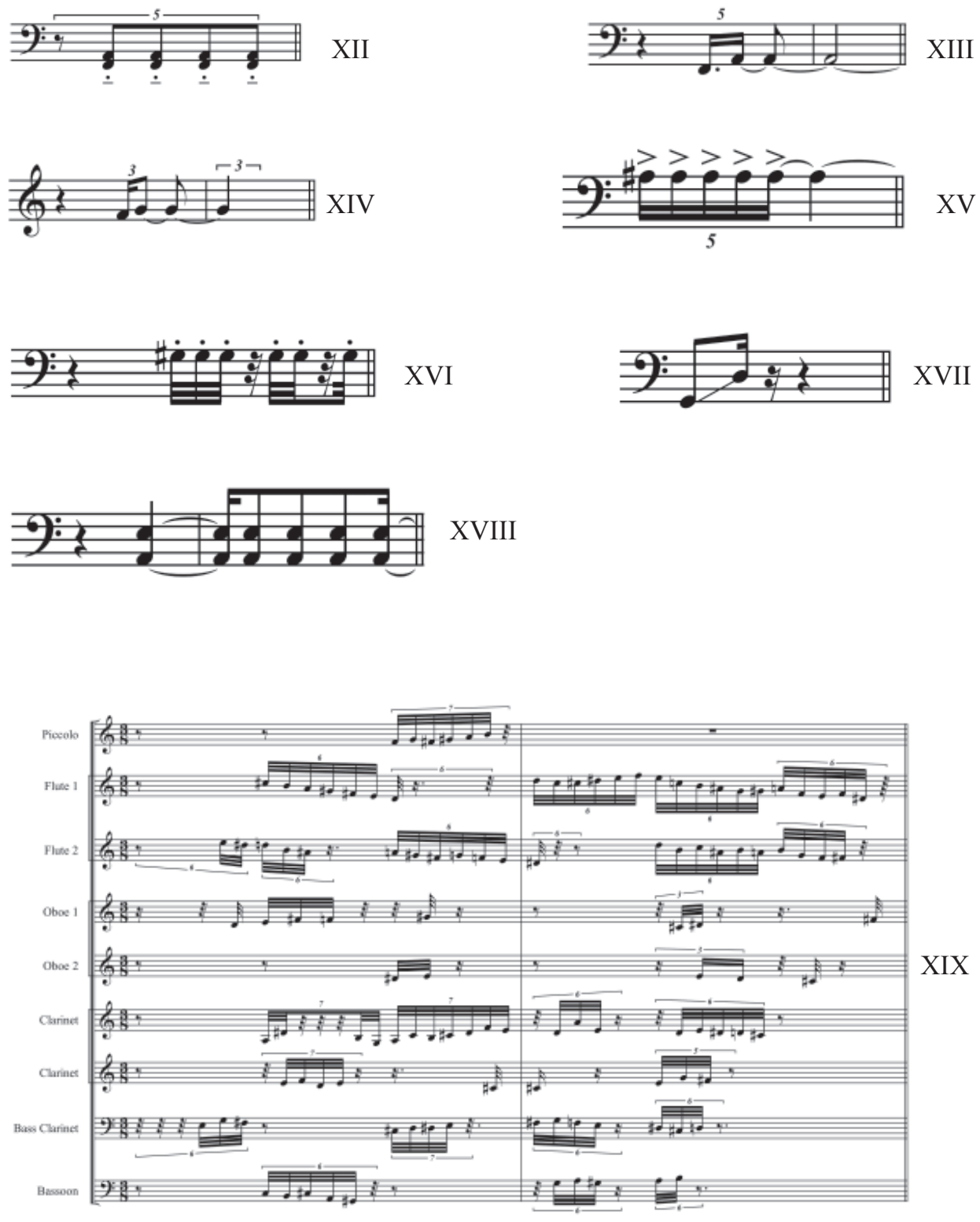

pedal tone or open fifth $\rightarrow \mathrm{XX}$ 
New Sound 39, I/2012
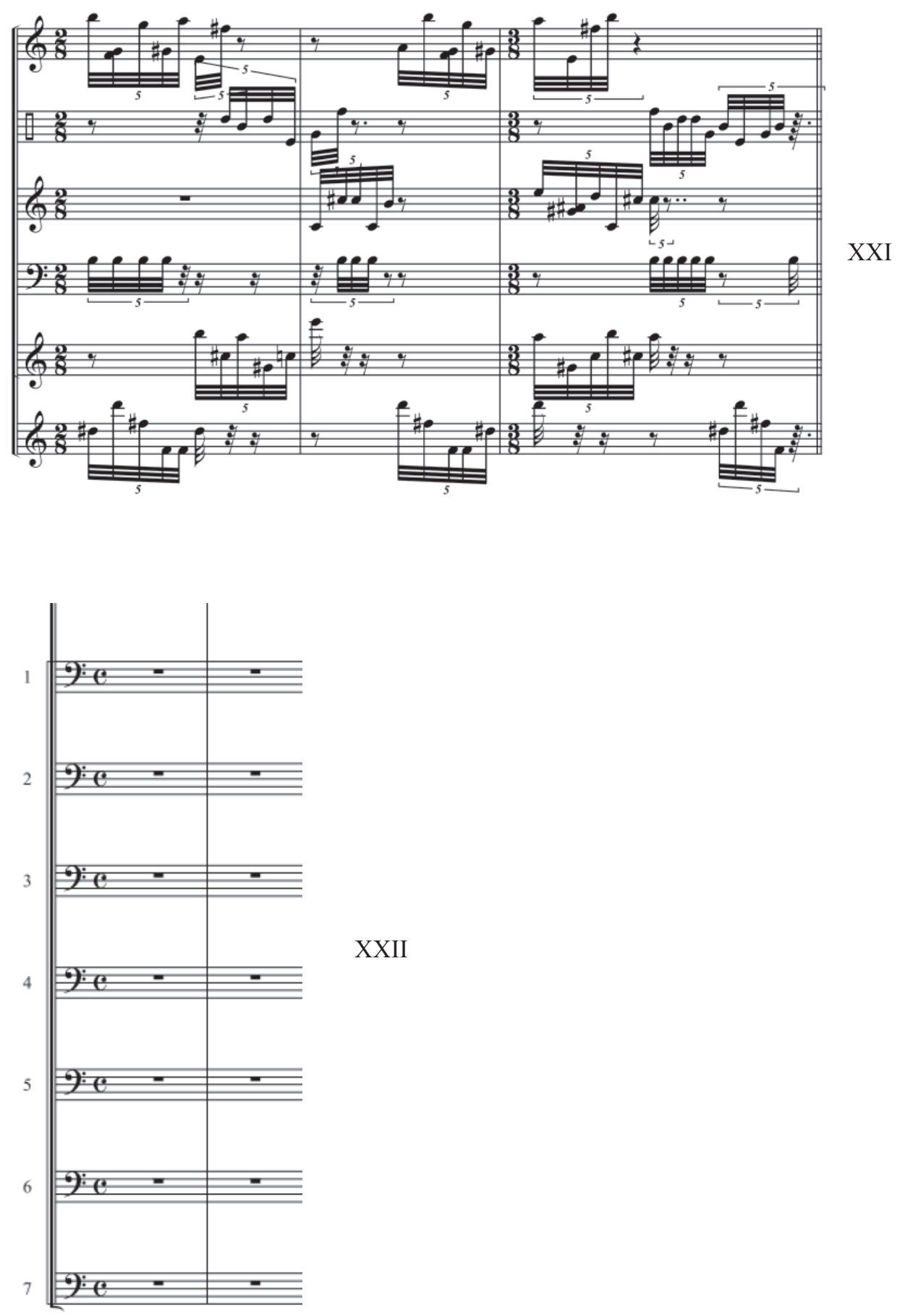

100 
Pompe, G.: Palimpsest And/Or Parody Technique ... (91-107)

This stock of twenty-three material splinters, however, shows no signs of arbitrariness. Closer comparison of the splinters reveals that they are derived from four main splinters, and that they build a dense thematic net. The principal splinters are:

- open fifth or interval of a perfect fifth (its best realisation is splinter II),

- repetitions of the same note (we find this idea in numerous splinters),

- intervals of a major or minor third in melodic and harmonic variants (this splinter occurs for the first time at the beginning of the first transition as splinter XII), and

- the motion of a minor or major second (the basis represents splinter XIV).

Thus splinters XVIII, XVII and XX are derived from the principal splinter of an open fifth (II, see table 2). The fundamental idea of repetitions (XXIII) represents the basis for the largest number of splinters - as its derivation functions as splinter $\mathrm{X}$, with characteristic harmonic tones, and this is later transformed into splinters XI, IV, V and III. In splinter XV, one finds diminished repetitions, which are also combined with pauses in splinter XVI. This logic of transformation of the idea of repetitions eventually gives rise to splinters XIX, XXI, VII and VII, in which rhythmic consistency is preserved but the pitches become wider and unstable. Splinter XII forms the basis for splinters XIII and VI (a descending minor third replaces the ascending major third), while splinter IX, which can be also linked to the idea of repetitions, is a derivative of splinter XIV.

However, the choice of the four basic material splinters was not left to chance, nor to the composer's free imagination. Closer comparison of the basic splinters with the beginning of Tallis's motet reveals that the splinters are derived from the first four bars of the motet, which are also literally quoted in Ruzicka's work. Thus Tallis's composition begins with the open fifth (see table 3 ) that Ruzicka exploits as splinter II. Then follow the repetitions in the upper voice (compare with splinter XXIII), while the lower voice successively introduces the intervals of a major and minor third (the basis for splinters XII and XIII). From the last bar, Ruzicka borrowed the motion in seconds $(e-d)$, which he inverted and set as the origin of splinter XIV. 
New Sound 39, I/2012

Table 2: The "motivic net" between splinters.

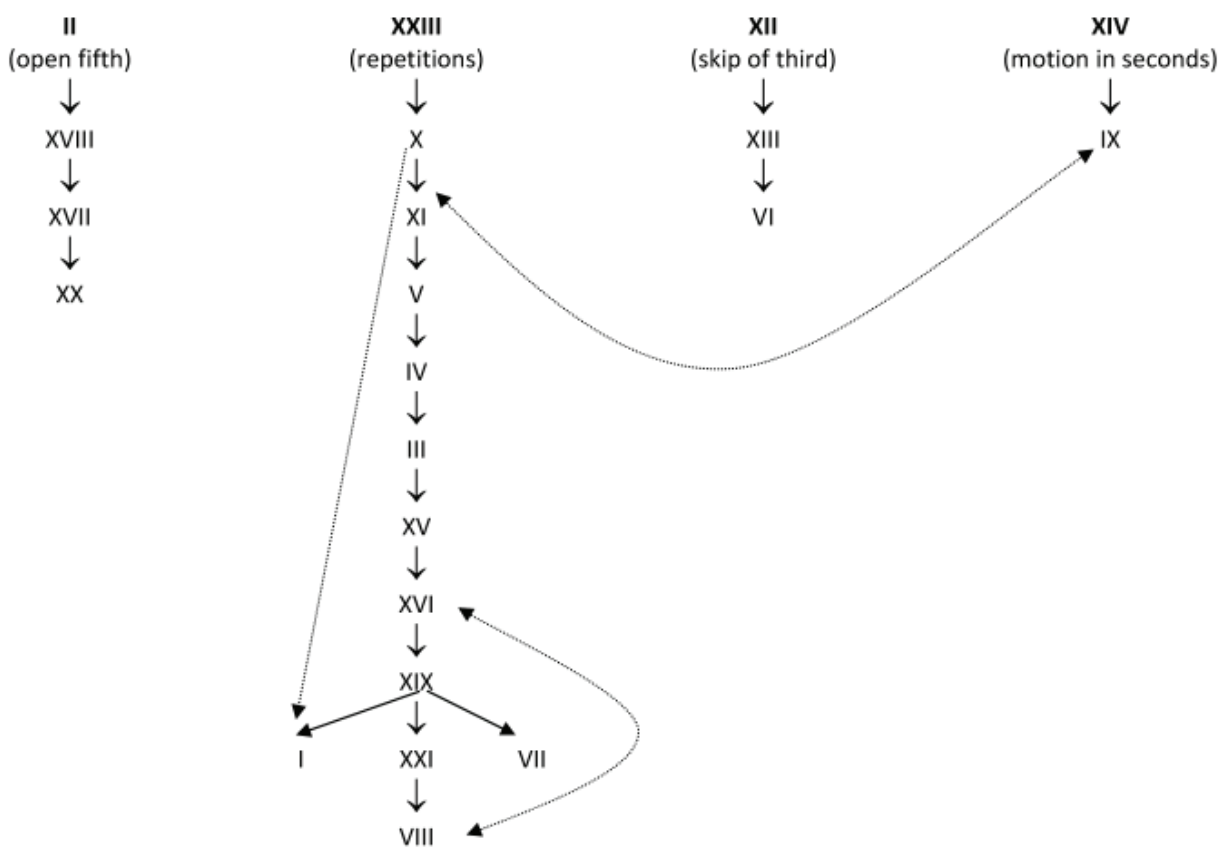

Table 3: The derivation of the basic material splinters from the beginning of Tallis's composition Spem in alium.

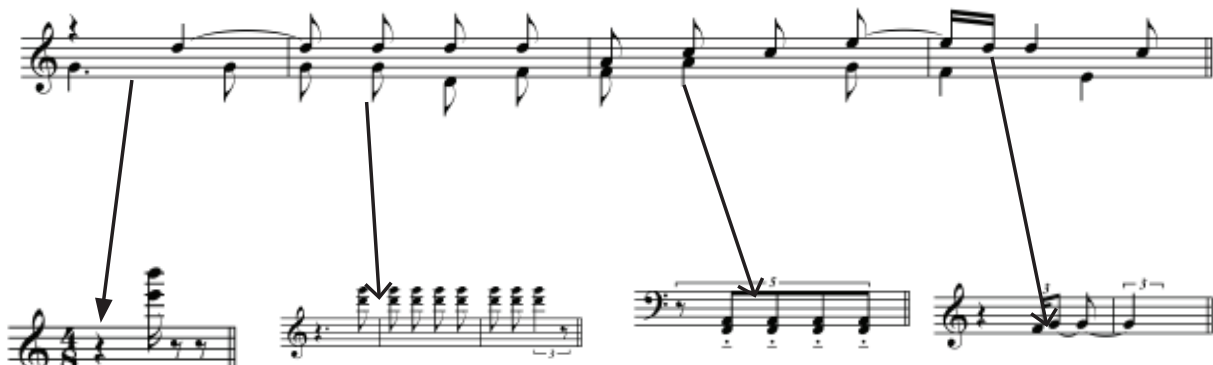

open fifth (II) repetitions (XXIII) major third (XII) inversion of motion in seconds $(X I V)$ 
Tallis's motet therefore enters Ruzicka's composition on two levels: on the level of semantically accentuated allusions and quotations, and on the material level - splinters are derived from the beginning of Tallis's composition. This fact reveals Ruzicka's central idea: his composition is conceived as a kind of play between approaching and withdrawing from Tallis's motet, which is a common procedure of Ruzicka's within the frameworks of his concept "music about music", and can also be found, for example, in his composition for string quartet ...übereinVerschwinden(1992). ${ }^{21}$ A similar interplay of approaching and withdrawing also marks the series of Tallis allusions that can be found in both of the main parts of Ruzicka's composition: paraphrases a-c, e, $h-j$, quotation d and "intrusions" $\mathrm{f}-\mathrm{g}$ (see table 1 and compare with example 2). In the first part, these form a sequence that leads from the most distant and distorted allusion (a) to literal quotation in intrusions ( $\mathrm{d}, \mathrm{f}-\mathrm{g})$, while in the second part Ruzicka reverses this procedure: paraphrases $(\mathrm{h}-\mathrm{j})$ now withdraw from the central quotation. Such interplay paradoxically causes the loss of the boarders between seemingly very distant stylistic layers: Tallis's Renaissance layer and the modernist layer of sound masses resulting predominantly from innovative instrumental techniques (particularly distinctive are the opening string harmonics and various kinds of pizzicato) and typical harmonic clusters. Tallis reminiscences dominate the whole composition but appear in different forms: as literal quotations, allusions or as heavily modified paraphrases that are impossible to distinguish from Ruzicka's original, modernist layer.

Example 2: Approaching and withdrawing from the literal quotation.
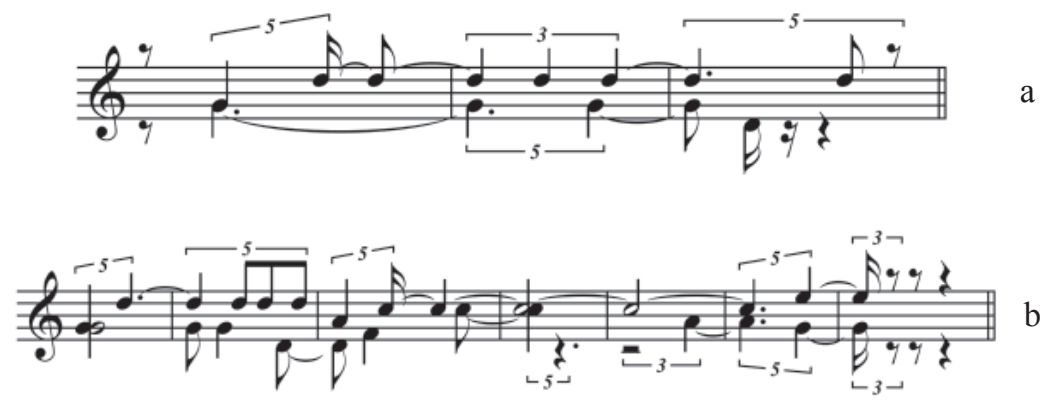

${ }^{21}$ Auli Eberle, "Das musikalische Phänomen der Stillebei Peter Ruzicka. Anmerkungen am Streichquartett über ein Verschwinden”, in: “... den Impulszum Weierspercehnerstempfinge”. Peter Ruzickazum 60.Gerburtstag, ed. by Thomas Schäfer, Saarbrücken, PFAU 2008, p. 65. 
New Sound 39, I/2012
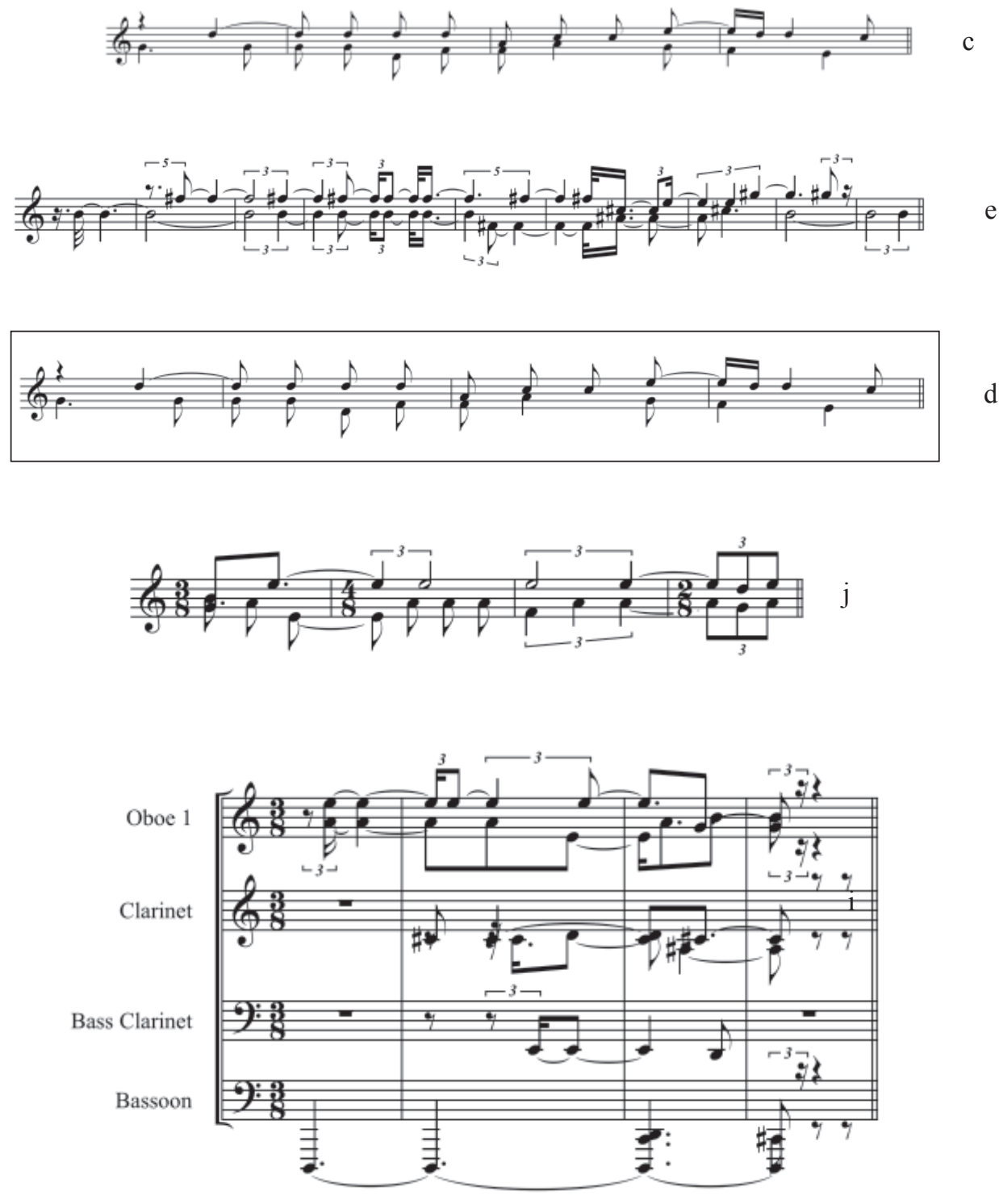


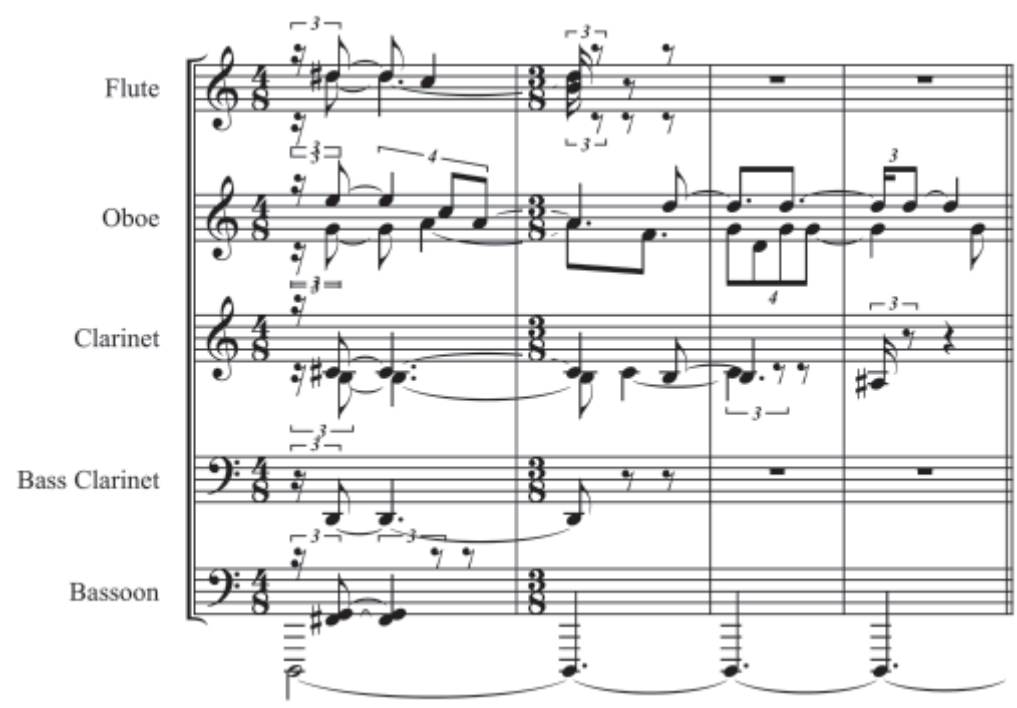

\section{Final remarks}

The results of the analysis throw important light on our central dilemma about the relationship between modernism and postmodernism. Ruzicka's piece Tallis is torn between numerous tension couples. We have already mentioned the two layers of Tallis - the layer of allusions and the layer of material - that penetrate Ruzicka's composition. However, the piece can also be observed in two ways regarding the main compositional procedures: the quotations and paraphrases of Tallis's motet that shine through the dense modernist texture expose the typical idea of palimpsest, but, on the other hand, the dependence of the main material splinters on Tallis's piece could be indicative of parody technique. The idea of "music about music" clearly causes a kind of stylistic divergence: the material originates from Renaissance polyphony but is then wrapped in a modernist sound coat. Listening to Ruzicka's piece does not, however, raise questions about homogeneity or heterogeneity - a dilemma that was for some time central to Hermann Danuser's definition of postmodernism ${ }^{22}$ - but instead

${ }^{22}$ Danuser first claims that the main characteristic of postmodern collage techniques is their heterogeneity ("Musikalische Zitat - und Collageverfahren in Lichte der (Post)Moderne-Diskussion", Bayerische Akademie der Schönen Künste: Jahrbuch 4 (1990), pp. 395-409) but later changes his mind with the assumption that the same techniques had already been used by modernist composers, and that postmodernists strive for homogeneity of material and ideas ("Zur Kritik der musikalischen Postmoderne" in: Quo vadis musica? ed. by Detlef Gojowy, Kassel, Bärenreiter 1990, pp. 82-91). 
gives us the impression that both layers - the non-modernist and modernist have been amalgamated.

The inner motive of such an amalgam is the interplay between approaching and withdrawing from Tallis's pretext. This kind of texture, which here and there allows a glance at the original Tallis and later again covers it with a modernist blanket, ignites semantic potentials. The "parallel constructing" of two "worlds" - Tallis's Renaissance and Ruzicka's contemporary context - open autoreflexivity on the present state of musical material, technique and style. It is precisely this semantic "questioning", the positioning of "semantic enclaves" in the predominant "sea" of modernist sound and procedures, that can be regarded as a typical postmodern characteristic. Although it seems that Ruzicka's compositional techniques stem predominantly from the arsenal of modernist procedures, such contextual clashes load the piece with semantic charge. The basic postmodernist idea lies not in quoting per se but in the semantic potential that quotations evoke.

In Ruzicka's composition Tallis, it is almost impossible to find the clear diving line between modernist and non-modernist impulses in the composer's interplay between approaching and withdrawing in the process of the palimpsest/parodic manipulation of the "original" layer. It is precisely this ambivalence that reveals the relationship between modernism and postmodernism - the latter stems from modernism and uses its techniques, but at the same time pierces these techniques with intrusions of non-modernist "enclaves" that trigger accentuated semantics. In this light, postmodernist commitment to modernism appears to be of key importance. The case of Ruzicka's idea of "music about music" confirms the notion of postmodernism being a continuation and radicalisation of modernism: postmodernism should not be confused with anti-modernism.

\section{REFERENCES}

Danuser, Hermann, "Musikalische Zitat- und Collageverfahren in Lichte der (Post)Moderne-Diskussion", Bayerische Akademie der Schönen Künste: Jahrbuch 4, 1990, 395-409.

Danuser, Hermann, “Zur Kritik der musikalischen Postmoderne” in: Quo vadis musica? ed. by Detlef Gojowy, Kassel: Bärenreiter 1990, 82-91.

Dženks, Čarls, Jezik postmoderne arhitketure, transl. by O. Popović, Belgrade:Vuk Karadžić, 1985.

Eberle, Auli, "Das musikalische Phänomen der Stillebei Peter Ruzicka. Anmerkungen am Streichquartett über ein Verschwinden”, in: “... den Impulszum Weierspercehnerstempfinge”. Peter Ruzickazum 60. Gerburtstag, ed. by Thomas Schäfer, Saarbrücken: PFAU 2008, 65. 
Feller, Ross "Resistant Strains of Postmodernism: The Music of Helmut Lachenmann and Brian Ferneyhough", in: Postmodern Music / Postmodern Thought, ed. by Judy Lochhead and Joseph Auner, New York and London: Routledge 2002, 250.

Hatten, Robert S., Musical Meaning in Beethoven. Markedness, Correlation, and Interpretation, Bloomington: Indiana University Press, 1994.

Heile, Björn, "Collage vs. Compositional Control: The Interdependency of Modernist and Postmodernist Approaches in the Work of Mauricio Kagel”, in: Postmodern Music / Postmodern Thought, ed. by Judy Lochhead and Joseph Auner, New York and London:Routledge 2002, 288.

Kneif, Tibor, “Anleitungzum Nichtversteheneines Klangobjekts”, in: Musik und Verstehen. Aufsätze zur semiotischen Theorie, Ästhetik und Soziologie der musikalischen Rezeption, ed. by Tibor Kneif and Hans-Peter Reinecke, Köln: Arno Volk Verlag and Hans Gerig 1973, 167.

Kompridis, Nikolas, "Learning from Architecture: Music in the Aftermath to Postmodernism", Perspectives of New Music 31, 1993, No. 2, 7.

McHale, Brian, Constructing Postmodernism, London and New York: Routledge 1992.

Motte-Haber, de la, Helga, "Postmodernism in Music: Retrospection as Reassessment", Contemporary Music Review12, 1995, No. 1, 78.

Ruzicka, Peter, “'Den Impulszum Weitersprechen...' Versuch eines musikalischen Selbstportraits", in: Peter Ruzicka, Erfundene und gefundene Musik, ed. by Thomas Schäfer, Hofheim:Wolke, 1998, 18.

Ruzicka, Peter, "Erfundene und gefundene Musik. Bemerkungen zu einem bedeutsamen Dualismus der Neuen Musik", in: Erfundene und gefundene Musik, 54.

Schäfer, Thomas, “Anti-Moderne oder Avantgarde-Konzept? Überlegungen zur musikalischen Postmoderne", International Review of the Aesthetics and Sociology of Music, 26, 1995, No. 2, 221.

Schäfer, Thomas, “'Verschwiegene Lieder' - ein instrumentales 'Requiem' für Paul Celan”, Die Musikforschung 50,1997, No. 3, 295.

Sommer, Uwe, "Peter Ruzicka", in: Komponisten der Gegenwart, ed. by Hanns-Werner Heister and Wolfgang Sparrer, Munich: edition text + kritik, 1992.

Vattimo, Gianni, Konec moderne, transl. by S. Kutoš, Ljubljana: Literatura 1997, 10.

Virk, Tomo, Strah pred naivnostjo. Poetika postmodernistične proze, Ljubljana: Literatura, 2000, 38 .

Welsch, Wolfgang, Unsere postmoderne Moderne, Weinheim: $\mathrm{VCH}^{3}, 1991$. 